\title{
CHANGE MANAGEMENT: EXPERIENCES OF PRIVATE TVET COLLEGE EDUCATORS REGARDING VIRTUAL LEARNING DURING COVID-19
}

\author{
Adebunmi Yetunde Aina ${ }^{1}, \&$ Ayodele Ogegbo ${ }^{2}$ \\ ${ }^{1}$ Department of Educational Management and Policy Studies, University of Pretoria (South Africa) \\ ${ }^{2}$ Department of Science and Technology Education, University of Johannesburg (South Africa)
}

\begin{abstract}
This study explored the experiences of private TVET college educators regarding virtual learning during the Covid-19 school lockdown. The Kanter theory of change is adopted as the theoretical base in this study. Data collection was done through face-to-face semi structured interviews and non-participant observation. Collected data was analyzed using content analysis. Findings reveal that though participants have positive attitude toward the process of change required in transitioning from traditional environment to virtual environment, majority of them did not receive substantive training on how to use technology to support virtual teaching. However, educators indicated that the change process comes with several challenges such as technical problems, ineffective communication from management, workload, inadequate training, lack of access to ICT tools and lack of other structural support within the college which impacts their effective implementation of virtual teaching. Thus, teachers should be adequately prepared, supported and empowered to cope with the changes and transition processes involved to continue teaching in a virtual environment. More so, TVET college managers and policy makers should priorities change management programmes designed to prepare teachers for the inevitability of technological change in education.
\end{abstract}

Keywords: Change management, educator, traditional classroom, virtual classroom, TVET college.

\section{Introduction}

In virtual learning context Parlakkic (2017 p. 640) described change management as the "combination of processes, activities, and approaches that manage the people of the organization through the transition from the old way of teaching to new e-learning". Parlakkic (2017) further indicates that it is very difficult to change the behaviours, culture and routine of the educational institutions' users such as the students, educators, school leaders. In agreement with Partlakkic, change will be tougher when the change process is sudden and forceful such as what most of the schooling system have to do in order to ensure continuity of teaching and learning during the school lockdown cause by the novel Coronavirus (Covid-19).

The outbreak of the Covid-19 has caused a shift in almost every system or model in the world's civilization and the education model has been no exception to this change. On the 15th of March 2020, the President of South Africa declared a national state of disaster and announces the institution of a nation-wide lockdown, including the closing of schools from the 18th of March 2020 (Haffajee 2020). The Basic education minister further announced that various platforms will be used to ensure that learning continues from home, i.e., online, radio and television platforms (Brodie, McFarlane and Ally, 2020). The introduction of the fourth industrial revolution has since been moving the education system in the virtual learning direction. It is unfortunate that the Covid-19 pandemic has forced change upon the education system moving from traditional learning to virtual learning; however, it is important to understand how educators experience the changing process. Hence this study aims at exploring and describing the experiences of private TVET college educators in Pretoria regarding virtual learning during the school lockdown. The research questions to achieve this aim are "What are the experiences of TVET college educators when transitioning from traditional learning to virtual learning during Covid-19 school lockdown?" and "what are the factors that inhibit and support TVET college educators transitioning from traditional learning to virtual learning?" 


\section{Literature}

Technologically, the world is changing so fast. Hence, educators should be in a position to adapt to these changes and still able to deliver quality teaching. The fourth Industrial revolution brought about changes in our teaching and learning environment globally including South African schools. Ramorola (2013) points out that the new focus on use of Information Communication Technology (ICT) in South African schools indicates that educators are expected to use computers and other technologies as tools to adopt the new and evolving teaching methods. For educators to effectively adapt to use of technologies (virtual classroom) in the place of the usual face-to-face traditional classroom, many factors must be put into consideration such as the educators understanding of virtual learning, educators' readiness or attitudes towards technology, availability of the relevant tools and training.

Educators, students, and administrators are used to traditional pedagogy, research constantly report that virtual learning projects are failing to achieve their objectives due to many reasons, more pronounce in the reasons is the user resistance to change (Parlakkilic, 2017 p. 638). Parlakkilic (2017 p. 642) further state that there are different views about the nature and aims of ICTs in education consequently, diverse behaviours and attitudes are found in the development, use and change management of virtual learning. In line with Parlakkilic finding regarding use of virtual learning, this present study seeks to explore and describe TVET college educators' regarding virtual classroom during the school lockdown.

Technical and vocational education and training play an essential role in increasing a knowledgeable and skilled community that will be able to effectively improve the social and economic growth of a country (DHET, 2013 p.3). Similarly, Boateng (2012 p. 108) described vocational technical education as the educational courses that involve the study of technologies and the gaining of practical skills and knowledge in order to discover and improve labor in various part of economic for the purpose of economy growth. For the TVET colleges to achieve skills development for economy growth, effective management from the relevant stakeholder is vital especially the educators' ability to manage change process that would enhance their performance during teaching and learning engagement with the students.

\section{Theoretical framework}

The Kanter theory of change is adopted as the theoretical base in this study, given its correlation with the researchers' intentions to explore and describe the experiences of TVET college educators when transitioning from traditional classroom to virtual classroom particularly during the Covid-19 school lockdown. The Kanter theory buttressed this study by highlighting how TVET educators managed the change processes involved, on account of their attitudes and behaviours during transitioning to virtual classroom. While different models and approaches have been developed to better understand the process change in organisations and educational settings as viewed by Kanter's theory, the particular areas of change that need to be articulated when addressing lecturers' experiences in this study utilizes the ADKAR model to provide a valuable interpretation of TVET college educators transformative efforts during the transition to virtual classroom.

\section{Methodology}

To achieve the objectives of the study, a qualitative research approach was used to obtain first-hand information in the research setting (Neuman, 2011); and to interpret and understand the participants experiences regarding their transitioning from traditional classroom to virtual classroom (Babbie \& Mouton, 2015). This study engaged a multiple case study research design as it was deemed most appropriate to obtain multiple information from various perspectives (Baxter \& Jack, 2008). The study focused on four private TVET colleges in Pretoria central to provide answers to the research questions. Case studies permits spending time in the setting of the research subject (Hamilton \& Corbett-Whitter, 2013). Table 1 depicts the educators' profile. 
Table 1. Educators profile.

\begin{tabular}{|l|l|l|l|l|l|}
\hline College & $\begin{array}{c}\text { Educators' } \\
\text { pseudonyms }\end{array}$ & \multicolumn{1}{|c|}{ Age } & Gender & Highest Qualification & \multicolumn{1}{c|}{$\begin{array}{c}\text { Years of teaching } \\
\text { experience in TVET } \\
\text { college }\end{array}$} \\
\hline \multirow{2}{*}{1} & Mr. A & 31 & Male & National Diploma & 6years \\
\cline { 2 - 6 } & Ms. B & 28 & Female & Bachelor of science Degree & 3years \\
\hline \multirow{2}{*}{2} & Ms. C & 27 & Female & Bachelor of science Degree & 3years \\
\cline { 2 - 6 } & Ms. D & 35 & Female & National Diploma & 6years \\
\hline \multirow{2}{*}{3} & Ms. E & 40 & Female & Bachelor of science Degree & 2years \\
\cline { 2 - 6 } & Ms. F & 40 & Female & Master's degree & 10years \\
\hline
\end{tabular}

Data was generated through face-to-face semi-structure interviews and non-participant observation of the ICT tools in the learning environment. The covid-19 restrictions were observed, during the interview sessions. Minimum of 45 minutes was spent with the participant at the college in order to understand them from their view. Data analysis was done thematically through analytically coding and categorizing the generated data into themes that emerged from the data. The research questions and conceptual framework also guided the researcher in the systematic analysis of data in terms of sorting it according to themes.

\section{Findings and discussion}

The findings are presented and discussed in the three sub-headings below.

\subsection{Attitude of TVET college educators toward virtual learning}

In the aim of attempting to answer the research questions while analyzing the participants shared experience regarding virtual learning during the covid-19 school lockdown, it was discovered that most of the participants had a mixed feeling towards the changing process from the traditional learning to virtual learning. Majority of the participants have positive attitude about virtual learning however, the circumstances that surrounded their movement negatively affected the change process from traditional learning to virtual learning. Mr. A and Ms. C, E and F described their feelings towards virtual learning as follow respectively -

"It is not that bad, but it is a bit challenging because of the rushing to change due to the national lockdown",

"I think online learning in itself is not a bad idea, but I don't think it can be the main mode of learning",

"I think virtual classroom is essential, I don't want us to go back to the traditional way of teaching"

"it's not boring asides the network issues which are the basic technical issues that we see regarding online classes. Online learning for me is actually more convenient".

The positive attitude displayed by majority of the participants towards the moving from traditional learning to virtual implies that there should be successful integration of virtual classrooms in our TVET colleges. However, the good attitudes displayed by the participants come with some hindrance which would affect the adoption of virtual learning in their colleges. The findings of this present study agree with Nokwali, Mammen and Maphosa (2017) in their study where they found that teachers have a positive view towards the idea of using ICTs in lessons. According to Torres \& Giddie (2020) teachers' attitudes towards technology, as well as their readiness to accept ICT into their teaching are key factors for the successful integration and use of technology in education. Similarly, Davis, Bagozzi \& Warshaw, (1989) in their Technology Acceptance Model (TAM) firmly indicate that attitude that users formed toward a system will actually determine if users will accept or reject it. Invariably educators' attitude towards virtual learning is important but more important are the situations surrounding the use of virtual learning. The following themes below are used to discuss factors that affect virtual learning in the participated TVET colleges.

\subsection{Supporting factor towards successful virtual learning}

Data collected through the interviews and observation revealed that the educators with background IT skills are in better position to successfully adapt to virtual learning despite the circumstance regarding the change process. For example, Mr A and Ms E said respectively that "For me I have IT background, I had certificate course in IT engineering, I have adequate knowledge on IT, so the changing from traditional classroom to virtual classroom was easy for me" and "Luckily for I was from 
the IT industry, so I was able to apply my background knowledge by giving them online activities with traditional face-to-face teaching". Data collection also reveals that the piece of trainings provided to the educators helped them during the moving from traditional classroom to virtual classroom. Although, the training seems not to be sufficient due to the short period that the educators have to change to virtual learning. This was narrated by Ms. E and B respectively "the institution tries to do some short training where online learning platform was explained", and "Immediately the President announced the national lockdown, decision was made to replace traditional classroom to virtual classroom by the college management and little or no form of training could be provided within that period". This finding indicates that training is essential to ensure smooth transitioning to virtual learning. In line with this finding is the recommendation made by Cheok, Wong, Ayub, and Mahmud (2017: 30) that "room to experiment, to make mistakes, to try again and finally learn must be made part of the school culture if change is expected". This implies that practical and continuous training regarding virtual learning should be provided for the educators.

\subsection{Mitigating factor towards successful virtual learning}

It was discovered from the analysis of the interviews and the observation of the learning environment of the participated TVET colleges that there is lack of ICT tools such as personal laptops for the educators, and access to Wi-Fi connection to facilitate virtual learning. According to the participants response, Mr. A said that "...there was not enough time for the school to provide the adequate and necessary materials such as laptops, android phones". He further stated that "the students also need the online garget like the phone, laptop, data, so that they can be able to stay online whenever they are having online classes. If students don't have any of these tools, it means that they will not be able to connect to the online classes" Similarly, Ms. C shared her experience regarding ICT tools "that is the biggest problem because the ICT gadget is lacking if I can say". Ms. D also added "in my college, lecturers were given data to work online but it is not frequent and sufficient. No provision regarding laptop or router for the lecturers. The students were also not supported with any resources needed for online learning. The students are on their own because this is a private college". The findings of this present study correlate with Nokwali, Mammen and Maphosa (2017) studies where they found that challenges such as a lack of ICT resources, space, and time compromises the teachers' ability to implement the use of ICT in lessons in an effective manner. This implies that lack of ICT tools would negatively affect the changing process from traditional classroom to virtual classroom. The lack of appropriate ICT tools experienced by the participants of this study made them to conclude that virtual learning has not come to stay but is just used to ensure continuity of learning during school lockdown. Ms. D stated that "I can say I have good attitude concerning online learning but the essential tools for online learning are not provided. So we have to move back to traditional learning because the students are expected to write national vocational examination in July". Ms. F added by saying "....not too much that was invested in the virtual learning, no infrastructure. So now that we are back to traditional learning, I can say that the virtual learning died a natural death".

\section{Conclusions}

Existing literature recognized the benefits of virtual learning and adapting ICT tools in learning environment to improve the output of education sector and transform the economy at the long run (Torres \& Giddie, 2020; Dlamini, Marais, Mwapwele \& Van Biljon, 2019: Rubagiza, Were \& Sutherland, 2011). However, the adaptation of virtual learning comes with several challenges (Nokwali, Mammen \& Maphosa, 2017). This study was an attempt to provide insights about the state of virtual learning in some selected TVET colleges in Pretoria by exploring the experiences of the educators regarding virtual learning during the school lockdown due to the Covid-19 pandemic. This study reveals that the participated TVET college educators have good attitude towards virtual learning. However, challenges such as ICT skills, training and lack of ICT resources made participants to conclude that virtual learning has not come to stay in their colleges. Hence, to ensure successful integration of virtual learning/ ICT in our TVET colleges it is recommended that the educators which be provided with practical and continuous training regarding virtual teaching and learning. It is also recommended that the Government should support the private TVET colleges which this study focused on regarding ICT resources to facilitate proper and progressive integration of virtual learning. 


\section{References}

Babbie, E. \& Mouton, J. (2015). The Practice of Social Research. London: Oxford University Press.

Baxter, P., \& Jack, S. (2008). Qualitative case study methodology: Study design and implementation for novice researchers. The qualitative report, 13(4), 544-559.

Boateng, C. 2012. Restructuring Vocational and Technical Education in Ghana: The Role of Leadership Development. International Journal of Humanities and Social Science, 2(4) 108-114.

Brodie, M., McFarlane, R., \& Ally N. (2020). Learning in the time of Covid-19: Equitable support during school closures desperately needed. Daily Maverick. [Online] Available from: https://www.dailymaverick.co.za/article/2020-04-21-learning-in-the-time-of-covid-19-equitablesupport-during-school-closures-desperately-needed/ [Accessed 5 September 2020].

Cheok, Mei Lick, Su Luan Wong, Ahmad Fauzi Ayub, and Rosnaini Mahmud. (2017). "Teachers' Perceptions of E-Learning in Malaysian Secondary Schools." Malaysian Online Journal of Educational Technology, 5(2), 20-33.

Davis, F. D., Bagozzi, R. P., \& Warshaw, P. R. (1989). User acceptance of computer technology: A comparison of two theoretical models. Management Science, 35(8), 982-1003.

Department of Higher Education and Training. 2013. White Paper for Post-School Education and Training: Building and expanded, effective and integrated post-school system. Pretoria: Government Printer.

Dlamini, S., Marais, M., Mwapwele, S. D., \& Van Biljon, J. (2019). Teachers' ICT adoption in South African rural schools: a study of technology readiness and implications for the South Africa connect broadband policy. The African Journal of Information and Communication, 24(1), 1-21. https://doi.org/10.23962/10539/28658

Haffajee, J. (2020). Ramaphosa shows mettle as he declares Covid-19 a national disaster and the world's gravest emergency. Daily Maverick. [Online] Retrieved from https://www.dailymaverick.co.za/article/2020-03-15-ramaphosa-shows-mettle-as-hedeclarescovid-19-a-national-disaster-and-the-worlds-gravest-emergency/ [Accessed 5 September 2020].

Hamilton, L., \& Corbett-Whittier, C. (2013). Defining case study in education research. Using case study in education research, 3-22.

Kanter, R. M., \& Stein, B. A. Jick. T.D. (1992). The challenge of organizational change: How companies experience it and leaders guide it. New York, United States: The Free Press.

Neuman, W. L. (2011). Social Research Methods. Qualitative and Quantitative Approaches. (7 $7^{\text {th }}$ Ed.). New York: Allyn and Bacon.

Nokwali, M., Mammen, K., \& Maphosa, C. (2017). How is technology education implemented in South African schools? View from technology education learners. International Journal of Education Sciences, 8(3), 563-571. Retrieved from doi:10.1080/09751122.2015.11890278

Parlakkiliç, A. (2017). Change management in transition to e-learning system. Qualitative and Quantitative Methods in Libraries, 3(3), 637-651.

Ramorola, M. Z. (2013). Challenge of effective technology integration into teaching and learning. Africa Education Review, 10(4), 654-670. Retrieved from https://doi.org/10.1080/18146627.2013.853559

Rubagiza, J., Were, E., \& Sutherland, R. (2011). Introducing ICT into schools in Rwanda: Educational challenges and opportunities. International Journal of Educational Development, 31(1), 37-43. Retrieved from https://doi.org/10.1016/j.ijedudev.2010.06.004

Torres, K. M., \& Giddie, L. (2020). Educator Perceptions and Use of Technology in South African Schools. Peabody Journal of Education, 95(2), 117-126. Retrieved from https://doi.org/10.1080/0161956X.2020.1745611 